\title{
KETENTUAN TENTANG SUNAT PEREMPUAN DIKAITKAN DENGAN ASAS GENDER DAN NONDISKRIMINATIF
}

\author{
Inna Noor Inayati, A. Widanti S dan Alma Lucyati \\ innanorinayati@yahoo.co.id \\ Magister Hukum Kesehatan \\ Universitas Katolik Soegijapranata Semarang
}

\begin{abstract}
ABSTRAK
Sunat perempuan masih dilakukan di beberapa wilayah di Indonesia dengan berbagai variasi dan berdampak negatif terhadap kesehatan. CEDAW dan WHO melarang praktik sunat perempuan. UUD 1945 dan UU No.36 Tahun 2009 tentang Kesehatan menyatakan praktik sunat perempuan melanggar hak reproduksi perempuan dan diskriminatf. Dalam melindungi perempuan dari praktik sunat, pemerintah mengeluarkan ketentuan tentang sunat perempuan dengan Permenkes No. 1636/MENKES/PER/XI/2010 tentang Sunat Perempuan. Penelitian menggunakan metode kualitiatif dan pendekatan yuridis normatif dengan spesifikasi penelitian deskriptif. Tehnik pengumpulan data terdiri dari data sekunder yang dikategorikan dalam bahan hukum primer, sekunder dan tersier. Analisis data menggunakan metode kualitatif normatif yaitu metode analisis yang dilakukan dengan pendekatan normatif. Penyajian data dilakukan bersamaan dengan analisa data berdasarkan kerangka teori dan pemahaman. Hasil analisis hukum positif dan asas lex superior derogat legi inferiori, ketentuan sunat perempuan melanggar hukum dan tidak sesuai dengan standar pelayanan kesehatan dan standar profesi tenaga kesehatan. Permenkes Sunat Perempuan tidak memberikan perlindungan terhadap hak dan kesehatan reproduksi perempuan dan bersifat diskriminasi sehingga dinyatakan tidak memenuhi asas gender dan nondiskriminatif.
\end{abstract}

Kata Kunci : Sunat Perempuan, Asas Gender, Asas Nondiskriminatif 


\section{PENDAHULUAN}

\section{Latar Belakang Masalah}

Kesehatan adalah bagian dari hak asasi manusia yang dinyatakan dalam Deklarasi Hak Asasi Manusia. Kesehatan reproduksi merupakan bagian dari kesehatan merupakan hak asasi setiap orang. Saat ini, banyak masalah kesehatan reproduksi perempuan di Indonesia yang belum di akses secara maksimal terutama yang berkaitan dengan gender dan diskriminasi terhadap perempuan. PBB menyatakan bahwa terpenuhinya hak-hak reproduksi perempuan merupakan salah satu penentu dari program pembangunan di suatu negara. The Vienna Declaration and Program of Action tahun 1993 menyatakan bahwa pentingnya usaha penghapusan kekerasan terhadap perempuan dan efek buruk dari praktek-praktek tradisional atau kebiasaan tertentu dan prasangka budaya serta ekstrim agama. Contoh paling relevan mengenai perampasan hak reproduksi perempuan adalah praktik sunat perempuan. Menurut penelitian yang dilakukan oleh Rahmah Ida dalam buku Sunat Membelenggu Adat Perempuan Madura, ${ }^{1}$ persoalan sunat perempuan sangat berkaitan dengan kesehatan reproduksi perempuan, persepsi masyarakat tentang konstruksi gender dan diskriminasi terhadap perempuan.

Konferensi Perempuan tahun 1995 menegaskan bahwa perusakan alat kelamin perempuan yang diakibatkan Female Genital Mutilation (FGM) merupakan bentuk diskriminasi terhadap perempuan yang harus di hapuskan. CEDAW menyatakan mengutuk diskriminasi terhadap perempuan dan menghapuskan undaang-undang, peraturan, kebiasaan dan semua praktik yang diskriminatif terhadap perempuan. Komitmen pemerintah terhadap perlindungan hak reproduksi yang berkeadilan gender dan nondiskriminasi, ditegaskan melalui UndangUndang No. 7 Tahun 1984 tentang Pengesahan Konvensi Mengenai Penghapusan Segala Bentuk Diskiriminasi Terhadap Wanita, Undang-Undang No. 39 tahun 1999 tentang Hak Asasi Manusia dan Undang-Undang No. 36 tahun 2009 tentang Kesehatan.

Sebagai isu gender dan diskriminatif terhadap perempuan, sunat perempuan merupakan fenomena sosial yang perlu mendapat perhatian dari pembuat kebijakan. Pemerintah Indonesia telah mengeluarkan regulasi yang mengatur tentang sunat perempuan yaitu dikeluarkannya peraturan Menteri Kesehatan No. 1636 tahun 2010 tentang Sunat Perempuan. Akan tetapi peraturan ini menjadi perdebatan di masyarakat karena tidak sesuai dengan asas CEDAW dan Undang-Undang Kesehatan, dimana ketentuan ini diasumsikan bias gender dan diskriminatif. Pengintegrasian perspektif gender ke dalam suatu peraturan perundang-undangan dan atau kebijakan teknis operasional sangat penting untuk mewujudkan keadilan gender dan mencegah perlakukan diskriminatif khususnya terhadap perempuan $^{2}$.

\section{Perumusan Masalah}

Berdasarkan latar belakangmasalah di atas, maka perumusan masalah dalam penelitian ini adalah sebagai berikut:

\section{“Bagaimana ketentuan tentang sunat perempuan menyebabkan dipenuhinya asas gender dan nondiskriminatif ?"}

\footnotetext{
1 Rahmah Ida, 2005, Sunat Membelenggu Adat Perempuan Madura, Yogjakarta: Pusat Studi Kependudukan dan Kebijakan Universitas Gadjah Mada, Cet.Pertama, HIm. vi

2 Ida Soselo Wulan, 2012, Parameter Kesetaraan Gender Dalam Pembentukan Peratutan Perundang-Undangan, Jakarta: Kementrian Pemberdayaan Perempuan dan Perlindungan Anak, cetakan ke-2, HIm. v
} 
Untuk mendapatkan gambaran yang sistematis, diidentifikasikan beberapa aspek dalam masalah penelitian yang mencakup:

a. Bagaimana ketentuan tentang sunat perempuan?

b. Bagaimana asas gender dan nondiskriminatif berkaitan dengan ketentuan sunat perempuan?

c. Bagaimana ketentuan tentang sunat perempuan menyebabkan dipenuhinya asas gender dan nondiskriminatif?

\section{Metode Penelitian}

Metode penelitian ini menggunakan metode kualitiatif dengan menggunakan pendekatan yuridis normatif. Metode pendekatannya adalah metode penelitian yuridis normatif yaitu "penelitian yang difokuskan untuk mengkaji penerapan kaidah-kaidah atau norma-norma dalam hukum positif". ${ }^{3}$ Pendekatan yang dilakukan adalah pendekatan perundang-undangan (statute approach) dan pendekatan konsep (conceptual approach). ${ }^{4}$ Spesifikasi penelitian deskriptif yaitu dengan melakukan kajian-kajian masalah hukum yang masih bersifat melakukan infentarisasi hukum positif dan mengklasifikasikan hukum positif itu menjadi berbagai kategori hukum. ${ }^{5}$ Tehnik pengumpulan data menggunakan bahan pustaka dan studi dokumentasi yang berisi bahan hukum primer, sekunder dan tertier. Analisis penelitian ini menggunakan metode kualitatif normatif. Penyajian data dilakukan bersamaan dengan analisa data berdasarkan kerangka teori dan pemahaman yang berkembang pada saat menafsirkan data. ${ }^{6}$

\section{PEMBAHASAN}

\section{Ketentuan Sunat Perempuan}

Menurut Sumarmi yang mengutip pernyataan Dawala yang menyatakan bahwa sunat perempuan merupakan kekerasan seksual dan kekerasan sosial yang harus di tanggung perempuan demi nilai-nilai perkawinan dan identifikasi sosial yang menempatkan perempuan sebagai simbol identitas moralitas budaya yang harus di pelihara. ${ }^{7}$ Oleh sebab itu diperlukan kerangka hukum tentang ketentuan sunat perempuan berdasarkan tinjauan hukum positif yang akan menjadi landasan bagi peningkatan kesetaraan gender dan pengurangan diskriminasi terhadap perempuan. Interpretasi ajaran agama yang konservatif mengenai peran gender, yang banyak menyebabkan dikeluarkannya berbagai peraturan yang dipengaruhi oleh ajaran agama, yang membatasi kebebasan dan hak-hak manusia. Berpedoman pada hukum positif, diperlukan suatu langkah praktis dan strategis untuk menciptakan dan mewujudkan peraturan perundang-undangan tentang sunat perempuan yang materi muatannya sensitif dan responsif gender, memperhatikan aspek kesehatan reproduksi dan perlindungan anak khususnya anak perempuan akan menjadi sangat penting agar polemik dan aspirasi masyarakat tentang sunat perempuan dapat diwadahi dalam suatu bentuk pengaturan yang responsif gender dan nondiskriminatif. ${ }^{8}$

\footnotetext{
3 Johnny Ibrahim, 2011, Teori dan Metodelogi Penelitian Hukum Normatif, Bayumedia Publishing,HIm. 295. $4 \mathrm{lbid}, \mathrm{HIm}$. 390-391.

5 A.Widanti,2009, Petunjuk Penulisan Usulan Penelitian dan Tesis, Semarang: Universitas Katolik Soegijapranata. HIm 8.

6 Ibid. HIm 9-12.

7 Sumarni, 2005, Sunat Perempuan di bawah baying-Bayang Tradisi, Yogjakarta: Pusat studi Kependudukan dan Kebijakan Universitas Gadjah Mada,HIm.14

8 Kertas Kebijakan Kesetaraan Gender Indonesia, 2012, Jakarta: Kementrian Pemberdayaan Perempuan Dan Perlindungan Anak RI dan Kementrian Perencanaan Pembangunan Nasional, HIm. 3-5
} 
Untuk melakukan evaluasi suatu ketentuan dinyatakan diskriminatif atau bias gender dan mengakibatkan ketidakadilan, karena kalau demikian berpedoman pada konvensi CEDAW , UUD 1945, UU no. 39 Tahun 1999 tentang HAM, UU No. 23 tahun 2002 tentang Perlindungan Anak dan UU No. 36 Tahun 2009 tentang Kesehatan yang menjadi tolak ukur dalam mengevaluasi suatu peraturan dibawahnya. Dengan berpangkal tolak pada perlindungan hukum berdasarkan asas gender dan nondiskriminatif, hukum dan kebijakan harus menyerasikan benturan dan pertentangan berbagai aspek, dengan memberikan respons yang bertanggungjawab dengan hukum yang responsif, yaitu hukum yang memberikan respons yang bertanggungjawab secara de jure dan de facto dalam kesetaraan, keadililan gender dan nondiskriminatif yang secara nyata dapat dinikmati perempuan dan laki-laki. Agar hukum menjadi responsif, maka sistem hukum harus terbuka terhadap tantangan, mendorong partisipasi dan responsif terhadap masalah-masalah yang timbul karena munculnya kepentingan-kepentingan baru dalam masyarakat. Untuk itu perlu adanya pembaharuan Sistem Hukum Nasional dengan sistem terbuka, menegakan nilai-nilai filsafat, budaya, hukum yang menunjukkan pada jati diri bangsa Indosesia. Selain itu Sistem Hukum Nasional harus dapat menggambarkan interaksi dengan lingkungannya baik nasional maupun internasional.

Dalam hal ketentuan tentang sunat perempuan agar tidak diindikasikan bias gender dan diskriminatif, hendaknya dirumuskan dengan memperhatikan dan mempertimbangkan asas Hukum Internasional dan Hukun Nasional yang berkaitan dengan kesehatan reproduksi perempuan yang berkeadilan gender dan nondiskriminatif, sehingga ketentuan tersebut akan mengakomodir kebutuhan spesifik gender, mencerminkan pengaturan yang transformatif gender, berorientasi pada aspek perlindungan dan pemulihan atas praktek ketidakadilan gender serta non diskriminatif baik terhadap diri perempuan maupun laki-laki ataupun kelompok rentan lainnya.

Dalam melakukan analisis ketentuan sunat perempuan secara yurisidis normatif berdasarkan subtansi asas hukum berlaku asas hukum lex superior derogat legi inferior. Artinya hukum yang lebih tinggi lebih diutamakan pelaksanaannya daripada hukum yang lebih rendah ${ }^{9}$. Dalam hal ini hukum yang lebih tinggi dan menjadi rujukan dalam sunat perempuan adalah hukum Internasional yaitu konvensi CEDAW dan hukum Nasional yang terdiri dari Undang-Undang Dasar 1945, Undang-Undang tentang Hak asasi Manusia, Undang-Undang tentang Perlindungan Anak dan Undang-Undang tentang Kesehatan. Konvensi CEDAW secara tegas melarang praktik sunat perempuan dalam bentuk dan alasan apapun. Selanjutnya Konvensi Internasional tentang Hak Asasi Manusia tahun 1993 menyatakan bahwa pemerintah berkewajiban untuk menghapus diskriminasi atas perbedaan jenis kelamin telah menjadi salah satu misi yang melekat dalam rangka mencapai kesetaraan gender. ${ }^{10}$ Secara umum, hukum internasional menyatakan sunat perempuan merupakan bentuk diskriminasi dan kekerasan terhadap perempuan sehingga harus dihapuskan.

Surat Edaran yang dikeluarkan Dirjen Binkesmas tahun 2006 tentang Larangan Medikalisasi Sunat Perempuan bagi Petugas Kesehatan, menyatakan tenaga medis tidak boleh membantu melakukan praktik tersebut sebagai upaya mendukung segala usaha untuk menghapus tindak kekerasan terhadap perempuan. Hal ini merupakan salah satu bentuk konsistensi Indonesia dalam mendukung terlindungnya hak perempuan terhadap segala bentuk diskriminasi, termasuk kekerasan. Permenkes tentang Sunat Perempuan yang berisi tentang tatacara tindakan sunat perempuan, bertentangan dengan prinsip CEDAW dan HAM yang melarang sunat perempuan yang merupakan praktik kekerasan dan diskriminasi terhadap perempuan. Komitmen pemerintah Indonesia sebagai negara anggota Perserikatan

9 Marwan Mas, 2011, Pengantar Ilmu Hukum, Bogor: Ghalia Indonesia, HIm.122. 10 Ibid, HIm. 11-12. 
Bangsa Bangsa dan sebagai negara yang meratifikasi CEDAW, harus berkomitmen untuk menghapuskan praktik perusakan alat kelamin perempuan berupa tindakan sunat perempuan.

Hukum di Indonesia tidak secara eksplisit mencantumkan pelarangan terhadap sunat perempuan. Akan tetapi beberapa undang-undang dalam subtansinya menyatakan perlindungan terhadap anak dan kesehatan reproduksi perempuan serta menghapuskan segala bentuk diskriminasi, kekerasan dan ketidakadilan gender. Undang-Undang dasar 1945, Undang-Undang Kesehatan, Undang-Undang HAM dan Undang-Undang Perlindungan Anak, menjadi payung hukum tentang sunat perempuan. Dalam UUD 1945 Pasal 28 B ayat (2) dan pasal 28 I ayat (2) menyatakan bahwa hak anak untuk bebas dan mendapatkan perlindungan dari kekerasan dan diskriminasi. Undang-Undang Kesehatan Pasal 74 ayat (1) menyatakan bahwa setiap pelayanan kesehatan reproduksi harus memperhatikan aspek-aspek kesehatan reproduksi perempuan. Undang-Undang HAM Pasal 48 ayat (3) menyatakan bahwa hak reproduksi wanita dijamin dan dilindungi oleh hukum. Undang-Undang Perlindungan Anak Pasal 4 menyatakan bahwa anak berhak untuk mendapatkan perlindungan dari kekerasan dan diskriminasi. Permenkes ini meligitimasi praktik perusakan alat kelamin perempuan melalui tindakan sunat perempuan. Hal ini berlawanan dengan langkah pemerintah yang dituangkan dalam perundang-undangan untuk memperkuat kesetaraan gender, menghapuskan segala bentuk stereotype, diskriminasi dan kekerasan terhadap perempuan serta kesehatan reproduksi perempuan. ${ }^{11}$

Ketentuan yang menjadi dasar dalam Permenkes ini adalah ketentuan agama; dalam hal ini Agama Islam, standar pelayanan dan standar profesi. Ketentuan Agama Islam tentang sunat perempuan dijelaskan dalam Fatwa MUI No.9A tahun 2008 bahwa khitan terhadap perempuan adalah makrumah, pelaksaaannya sebagai salah satu bentuk ibadah yang dianjurkan. Dalam Fatwa tersebut menyatakan bahwa Surat Edaran Dirjen Binkesmas yang menyatakan pelarangan pada praktik sunat perempuan adalah bertentangan dengan ketentuan syari'ah, karena khitan bagi laki-laki dan perempuan termasuk aturan dalam syiar Islam. Fatwa dan Surat Edaran, dalam tatanan sistem hukum di Indonesia tidak memiliki kekuatan hukum. Apabila ketentuan agama (fatwa) dijadikan dasar ketentuan dalam Permenkes Sunat Perempuan, maka tidak sesuai dengan tatanan sistem hukum di Indonesia.

Ketentuan lain yang menjadi dasar dikeluarkannya Permenkes ini adalah ketentuan tentang standar pelayanan. Standar pelayanan kesehatan merupakan suatu pernyataan tentang mutu yang diharapkan, yaitu yang menyangkut masukan, proses, dan luaran dari sistem pelayanan kesehatan. Standar pelayanan bertujuan agar menjamin keseragaman spesifikasi teknis minimal yang harus dipenuhi, secara wajib akan melindungi klien dari tindakan yang membahayakan, memenuhi persyaratan karena terdeskripsi secara jelas dan kualitas dan keselamatan adalah acuan utama penerapan standar. Pengertian standar pelayanan dengan merujuk pada Permenkes No. 2052 tahun 2011 Pasal 1 ayat (9) adalah : "pedoman yang harus diikuti oleh dokter atau dokter gigi dalam menyelenggarakan praktik kedokteran"

Dengan mencantumkan SOP dalam ketentuan sunat perempuan, menjelaskan bahwa tindakan sunat perempuan merupakan tindakan medis (kedokteran). Hal ini bertentangan dengan Permenkes tentang ljin dan penyelenggaraan Praktik Kedokteran, bahwa tindakan medis harus dilakukan oleh tenaga medis (dokter), sedangkan dalam Permenkes Sunat Perempuan, tindakan sunat perempuan dilakukan oleh dokter, bidan, dan perawat. Bidan dan perawat tidak memiliki kewenangan dalam melakukan tindakan medis termasuk tindakan sunat perempuan.

11 Anwar Ibrahim, 25 Juli 2012, Sunat Perempuan Dikecam LSM, Internet: http://at.tarmudzi.blogspot.com/2012/03 
Selanjutnya, ketentuan tentang standar profesi menjadi dasar dalam Permenkes Sunat Perempuan. Dalam Standar Profesi Bidan, tidak dicantumkan tentang kewenangan dalam melakukan praktik sunat perempuan. Bahkan dalam standar kompetensi bidan menyatakan bahwa bidan harus memiliki pengetahuan tentang norma dan praktik budaya yang merugikan kesehatan reproduksi. Permenkes No. 148 tahun 2010 tentang Izin dan Penyelenggaraan Praktik Perawat tidak mencantumkan tentang kewenangan dalam melaksanakan sunat perempuan, begitu pula dalam Undang-Undang No. 29 Tahun 2004 tentang Praktik Kedokteran, tidak dicantumkan tentang standar pelayanan sunat perempuan.

Dalam Permenkes Sunat Perempuan mencantumkan SOP pelaksanaan sunat perempuan. Berdasarkan definisi SOP dalam Permenkes tentang Izin dan Penyelenggaraan Praktik Kedokteran, merupakan suatu perangkat instruksi/langkah-langkah yang dibakukan untuk menyelesaikan suatu proses kerja rutin tertentu yang memberikan langkah yang benar dan terbaik berdasarkan konsensus bersama untuk melaksanakan berbagai kegiatan dan fungsi pelayanan yang dibuat oleh fasilitas pelayanan kesehatan berdasarkan standar profesi. Berdasarkan standar profesi dokter, bidan dan perawat, tidak mencantumkan SOP tentang sunat perempuan. Hal ini bertentangan dengan ketentuan tentang SOP, dimana setiap SOP harus tercantum dalam standar profesi.

Berdasarkan analisis yuridis terhadap hukum positif di Indonesia, Permenkes tentang sunat perempuan melanggar Undang-Undang Dasar 1945, Undang-Undang HAM, UndangUndang Perlindungan Anak dan Undang-Undang Kesehatan.

\section{Asas Gender Dan Nondiskriminatif Dalam Ketentuan Tentang Sunat Perempuan}

Isu Gender dalam kesehatan adalah masalah kesenjangan perempuan dan laki-laki dalam hal akses, partisipasi, kontrol dan manfaat yang diperoleh mereka dalam pembangunan kesehatan. Kesenjangan akses, partisipasi, kontrol dan manfaat antara perempuan dan lakilaki dalam pelayanan kesehatan secara langsung menyebabkan ketidaksetaraan terhadap status kesehatan, sehingga isu gender tidak hanya dilihat dari pelayanan saja akan tetapi perlu melihat pada hubungan sosial budaya yang menyebabkan perbedaan status, peran relasi antara perempuan dan laki-laki di masyarakat. ${ }^{12}$

Dalam pembentukan hukum atau kebijakan berperspektif gender, menurut Dahl seperti yang dikutif Lapian memerlukan studi tentang deskripsi dan evaluasi tentang hukum , identifikasi dukungan hukum dan diskusi tentang apa dan bagaimana hukum yang memerlukan transformasi. Studi tersebut diperlukan untuk memberikan deskripsi tentang hak dan kewajiban hukum perempuan, memahami situasi hukum perempuan dan memperbaiki posisi perempuan dalam hukum dan masyarakat, yang bertujuan untuk mewujudkan kesetaraan dan keadilan gender artinya secara yuridis, de facto, dan subtantif serta adil antara perempuan dan laki-laki. ${ }^{13}$

Konstruksi sosial seperti itu dapat merugikan kedudukan perempuan atau laki-laki baik dalam membangun keluarga yang sehat dan sejahtera atau partisipasinya dalam pembangunan dan kegiatan masyarakat. Karena gender adalah produk budaya, maka gender dapat berubah dari waktu ke waktu sesuai dengan kondisi masyarakat serta bernegara, dapat berbeda diantara budaya bahkan di dalam budaya yang sama. Meskipun terdapat perbedaan dalam berbagai budaya dan waktu, hubungan gender di seluruh dunia mencerminkan relasi

12 Untung Suseno Sutarjo, 2010, Panduan Perencanaan dan Penganggaran Responsif Gender Bidang Kesehatan,Jakarta: Kementrian Kesehatan RI, Kementrian Pemberdayaan Perempuan dan Perlindungan Anak, UNFPA, HIm.7

13 L.M.Gandhi Lapian, 2012, Disiplin Hukum yang Mewujudkan Kesetaraan dan Keadilan Gender, Yayasan Pustaka Obor Indonesia, HIm. 25-26 
kekuasaan yang tidak seimbang antara laki-laki dan perempuan sebagai suatu ciri yang meresap (pervasive). ${ }^{14}$

Dampak adanya pandangan yang keliru tentang gender akan menumbuhkan asumsi yang bias gender dan diskriminatif. Hal ini membuktikan bahwa gender merupakan sesuatu yang bukan kodrati, dapat berubah dan diubah, bersifat tidak permanen, bisa dipertukarkan dan bersifat umum. Adapun sesuatu yang kodrati adalah hal yang sifatnya pemberian dari Tuhan merupakan ketentuan dan anugerah Tuhan Yang Maha Esa, bersifat kodrati, tetap dan tidak dapat diubah, tidak dapat dipertukarkan dan bersifat universal. Persoalan gender terjadi karena sejumlah perbedaan dan permasalahan yang muncul dan kehidupan bermasyarakat, yang kemudian menjadi satu kajian serius bagi sejumlah kalangan. Perbedaan dan permasalahan gender tersebut ditimbulkan karena banyak perbedaan yang muncul. Perbedaan-perbedaan itu di antaranya perbedaan gender melahirkan ketidakadilan, menimbulkan marginalisasi, menjadikan perempuan sebagai subordinasi, serta perbedaan gender menimbulkan diskriminasi.

Dalam Undang-Undang No. 12 tahun 2011 tentang Pembentukan Peraturan perundangundangan harus mencerminkan asas kesamaan kedudukan dalam hukum dan pemerintahan. Maksud asas tersebut adalah setiap muatan materi perundang-undangan tidak boleh berisi hal-hal yang bersifat membedakan berdasarkan latarbelakang, antara lain, agama, suku, ras, golongan, gender, atau status sosial. Pada dasarnya materi muatan suatu peraturan perundang-undangan tidak boleh mengandung atau mengakibatkan hal-hal yang bersifat diskriminatif, ketidakadilan, ketidaksetaraan, termasuk dalam hal gender. Salah satu upaya untuk memenuhi ketentuan di atas, maka perlu dilakukan pengkajian dan analisis terlebih dahulu tentang mengenai apa dan mengapa dibentuk suatu peraturan perundang-undangan, yang bertujuan agar peraturan tersebut, dikandung nilai-nilai keadilan baik dalam de-jure maupun de-facto nya. Salah satu langkah yang perlu dipertimbangkan adalah bentuk pengaturan yang responsif gender dan menghindarkan ketentuan yang netral gender serta non disriminatif sebagaimana yang dimaksud dalam prinsip-prinsip CEDAW.

Prinsip pembentukan kebijakan yang responsif gender adalah dengan melakukan analisis untuk mengidentifikasi kesenjangan situasi perempuan dan laki-laki serta faktor-faktor kebijakan dan praktik sosial, ekonomi dan budaya yang menyebabkannya sehingga mampu mengidentifikasi keadaan yang berkaitan dengan kesehatan perempuan dan laki-laki dalam berbagai aspek.

Menurut Lapian proses pembaharuan hukum untuk mewujudkan keadilan gender, seharusnya menggunakan kajian multidisiplin, karena aspek hukum suatu masyarakat saling mempengaruhi dan ditentukan oleh berbagai aspek seperti kekuatan berlakunya hukum, akuntabilitas yuridis, kekuasaan politik, interaksi masyarakat, pluralisme norma hukum, moral, kepercayaan dan agama. ${ }^{15}$ Dasar konvensi CEDAW adalah prinsip kesetaraan antara perempuan dan laki-laki yang menjamin bukan hanya kesetraaan yang ditentukan secara formal dalam ketentuan hukum, tetapi juga de facto dan subtantif yaitu kesetaraan yang sesungguhnya dan hasilnya dapat dinikmati secara nyata. Konvensi ini meletakan kewajiban pada negara untuk menjamin hak perempuan melalui proses legislasi, eksekutif dan yudikatif dengan mekanisme yang akuntabel. ${ }^{16}$

Kesepakatan CEDAW menjadi kewajiban negara yang harus segera dilaksanakan dalam upaya mempercepat tercapainya kesetaraan subtantif sebagaimana yang diamanatkan CEDAW. Dalam hal ini harus ada peran lembaga yang berwenang untuk melakukan pengawasaan dan uji materil terhadap perundang-undangan menjadi salah satu komponen

14 Untung Suseno, op.cit ,HIm.6-7.

15 L.M.Gandhi Lapian, op cit, Hlm. 35-37.

16 Ibid, HIm. 35-37. 
penting untuk menghapus diskriminatif. Pengawasan dapat dilakukan melalui yudicial rewiew, pengawasan pemerintah dan legislative review. ${ }^{17}$

The Vienna Declaration and Program Of Action dari Konferensi Dunia Hak Asasi Manusia tahun 1993 menyatakan bahwa pentingnya usaha penghapusan kekerasan terhadap perempuan dalam kehidupan privat dan publik, penghapusan semua bentuk pelecehan seksual, eksploitasi dan trafiking perempuan, penghapusan prasangka atas dasar jenis kelamin dalam pelaksanaan hukum, serta penghapusan konflik apapun yang dapat terjadi antara hak perempuan dan efek buruk dari praktek-praktek tradisional atau kebiasaan tertentu dan prasangka budaya serta ekstrim agama. ${ }^{18}$

Berkenaan dengan hak asasi perempuan, kenyataan menunjukan bahwa di lingkungan nasional dan internasional menghendaki ditegakannya kesetaraan keadilan gender dan nondiskriminatif. Hukum yang berusaha untuk menegakkan kesetaraan keadilan gender dan nondiskriminatif tergolong hukum yang responsif. Integritas hukum ditentukan oleh asasasasnya diantaranya asas gender dan nondiskriminatif. Pernyataan Moore (1988) seperti yang dikutif Ida Soselo Wulan menyatakan bahwa:

Akar persoalan agak sulitnya pemenuhan hak asasi perempuan, sangat terkait dengan nilai dan konsep budaya patriarkhi, yang menempatkan perempuan dan laki-laki pada relasi kekuasaan yang tidak setara. Pengalaman menunjukkan bahwa diskriminasi terjadi karena perempuan berasal dari golongan minoritas etnis, ras, warna kulit, kelas dan tentu saja karena setting sejarah tertentu. ${ }^{19}$

Dalam Peraturan Presiden Nomor 7 Tahun 2005 tentang Rencana Pembangunan Jangka Menengah Nasional Tahun 2004- 2009 menyatakan bahwa:

Masih rendahnya kualitas dan peran perempuan; tingginya tindak kekerasan terhadap perempuan dan anak; rendahnya kesejahteraan dan perlindungan anak; kesenjangan pencapaian pembangunan antara perempuan dan laki-laki; banyaknya hukum dan peraturan perundang-undangan yang bias gender, diskriminatif terhadap perempuan, dan belum peduli anak.

Permasalahan bahwa kesenjangan tersebut masih terus berlanjut sebagaimana dinyatakan dalam Peraturan Presiden Nomor 5 Tahun 2010 tentang RPJMN Tahun 2010-2014 bahwa:

Kualitas hidup dan peran perempuan masih relatif rendah, antara lain disebabkan karena:

1. Adanya kesenjangan gender dalam hal akses, manfaat dan partisipasi dalam pembangunan, serta penguasaan terhadap sumber daya, terutama pada tatanan antar provinsi dan antar kabupaten/kota.

2. Rendahnya peran dan partisipasi perempuan di bidang politik, jabatan publik, dan di bidang ekonomi.

3. Rendahnya kesiapan perempuan dalam mengantisipasi dampak perubahan iklim, krisis energi, krisis ekonomi, bencana alam dan konflik sosial, serta terjadinya penyakit.

Menurut Budi Hardiman, ada berbagai kendala yang menyebabkan sulitnya mewujudkan hak-hak asasi manusia adalah internalisasi hak asasi manusia menjadi ethos dan lifestyle masyarakat. Pertama, masyarakat kita cenderung mengembangkan kultur kewajiban dan hak dianggap berangkat dari tradisi konflik. Masyarakat cenderung bungkam terhadap pelangggaran hak asasi manusia yang dilakukan. Intensi hak-hak asasi manusia

17 Ida Soesilo Wulan, op.cit.,HIm 81-82

18 Ibid. HIm 82

19 Ibid. HIm.3 
sebagai susatu hak adalah melindungi masyarakat tidak hanya dari kekejaman orang lain, tetapi juga dari keinginan untuk berbuat kejam terhadap orang lain. Kegagalan mengerti intensi ini dikarenakan lemahnya secara teoritis dan praktis juga karena lemahnya kehandak baik. Kedua, peradaban hak asasi manusia mengandaikan pandangan bahwa manusia bertanggungjawab terhadap nasib dan sejarahnya sendiri (antroposentrisme) dimana pelanggaran hak asasi manusia dianggap sebagai kesalahan manusia yang bisa dituntut secara hukum. Sedangkan persepsi dalam masyarakat kita, pelanggaran hak asasi dilihat sebagai 'bencana' atau 'murka Tuhan' yang tidak dapat dituntut tanggungjawabnya kepada siapapun. Ketiga, peradaban hak asasi manusia seharusnya tumbuh dalam praktik republikanisme. Dalam masyarakat kita keterlambatan praktik republikanisme, dimana terdapat ketidakseimbangan yang mengakibatkan masyarakat terstatifikasi berdasarkan golongan dan kelompoknya. Selain itu sosialisasi hak asasi manusia tertantang oleh globalisasi yang memperparah solidaritas masyarakat. Terakhir, peradaban hak asasi manusia harusnya berkembang dalam dukungan agama, akan tetapi dalam masyarakat kita agama kurang memberikan dukungan terhadap hak asasi manusia, bahkan kerap sibuk dengan ritualisme dan narsisme atas kelompoknya. ${ }^{20}$

Di antara kesepakatan internasional, Konvensi CEDAW merupakan salah satu konvensi internasional, yang khusus mengenai hak asasi perempuan dengan pendekatan Kesetaraan Substantif, Non-Diskriminasi, dan Kewajiban Negara. Walaupun telah ditetapkan Deklarasi Umum Hak Asasi Manusia (DUHAM), Ketetapan Majelis Permusyawaratan Rakyat tentang Hak Asasi Manusia, jaminan pemenuhan Hak Asasi Manusia dalam Undang Undang Dasar Negara Republik Indonesia Tahun 1945, Undang-Undang Republik Indonesia Nomor 39 Tahun 1999 tentang Hak Asasi Manusia, dan diratifikasinya Kovenan Internasional tentang Hak Asasi Manusia, namun kenyataan menunjukkan bahwa prinsip "perempuan, sebagai manusia (human being) mempunyai hak yang sama (setara dan adil) dengan laki-laki dalam setiap bidang kehidupan" belum tercapai secara nyata sebagaimana yang diharapkan di Indonesia.

Ada beberapa faktor yang menyebabkan kerentanan, ketidakberdayaan, dan pemiskinan perempuan. Yang utama ialah ketidakfahaman bahwa hak asasi perempuan adalah hak asasi manusia, bahwa karena dia adalah perempuan, yaitu fungsi reproduksinya, memiliki kepentingan dan kebutuhan khusus yang berbeda dengan laki-laki. Ketidakfahaman ini dapat tersirat dalam berbagai peraturan perundang-undangan termasuk kebijakan teknis, sehingga tidak mudah bagi perempuan untuk mengakses hasil pembangunan secara setara dan berkeadilan. Dalam berbagai kebijakan, program dan kegiatan pembangunan, isu-isu gender dan perempuan masih belum sepenuhnya menjadi perhatian dan pertimbangan dalam menyusun capaian sasaran pembangunan, sehingga hasil-hasil pembanguan kurang dapat langsung dirasakan dan dinikmati manfaatnya secara adil, terutama bagi perempuan. ${ }^{21}$

Diundangkannya Undang-Undang Republik Indonesia Nomor 39 tahun 1999 tentang Hak Asasi Manusia, memuat hak asasi yang harus dilindungi, dimajukan, ditegakkan dan dipenuhi oleh seluruh masyarakat terutama oleh Pemerintah. Hukum internasional tentang HAM yang sudah diterima Indonesia akan mengikat berdasarkan hukum (legally binding) menjadi hukum nasional. Menurut Dayal keunggulan hak politik dan sipil di dunia barat telah menyebabkan terjadinya marjinalisasi hak sosial, ekonomi, dan budaya yang lalu dianggap sebagai masalah pembangunan ketimbang sebagai isu hak asasi manusia. Hal ini memunculkan perdebatan mengenai penentuan prioritas hak asasi manusia dengan topik perdebatan bukan pada apakah menentukan prioritas sebagai sesuatu yang dibolehkan, tetapi pada debat tentang kategori hak mana yang paling utama bagi martabat manusia dan mana yang tidak. Menentukan prioritas semacam ini telah mengurangi pengakuan terhadap hak asasi

20 F. Budi Hardiman, 2011, Hak-Hak Asasi Manusia: Polemik dengan Agama dan Kebudayaan, Yogyakarta: Kanisius. HIm. 
perempuan karena seringkali pelekatan hak untuk hidup (right to life) seorang perempuan tergantung pada dan ditengahi (mediated) melalui hak sosial budaya dan ekonomi. Oleh sebab itu dirasakan perlunya formulasi undang-undang yang secara khusus dimaksudkan untuk mendorong dan melindungi hak asasi perempuan. ${ }^{22}$

Pembentukan perundang-undangan dan kebijakan dapat dilakukan melalui berbagai pendekatan. Salah satu pendekatan yang diadopsi CEDAW yaitu korektif atau model kesetaraan substantif yang berfokus pada asumsi-asumsi di balik pembedaan serta dampaknya terhadap perempuan, yang membantu mengidentifikasi dan mengoreksi ketidakberuntungan. Pendekatan ini tidak hanya berfokus pada perlakuan yang sama di hadapan hukum, tetapi kesetaraan dalam arti dampak aktual dari hukum. Kesetaraan substantif mempertimbangkan dan memberikan fokus pada keragaman, perbedaan, ketidakberuntungan dan diskriminasi. Pendekatan substantif berusaha menghapus diskriminasi yang diderita oleh kelompok-kelompok yang tidak beruntung pada tingkat individu, kelembagaan, dan sistem, melalui tindakan-tindakan korektif dan positif. Perhatian utamanya adalah memastikan agar hukum melakukan koreksi atas ketidakseimbangan yang ada dan memberi pengaruh pada hasilnya dengan memastikan adanya persamaan kesempatan, akses, dan manfaat bagi perempuan. Untuk itu, pendekatan ini berusaha merubah paradigma dari perlakuan yang sama menjadi persamaan hasil (equality of outcomes). ${ }^{23}$

Terlepas dari tujuan dikeluarkannya ketentuan tentang sunat perempuan, praktik sunat perempuan yang dilakukan secara simbolis maupun perusakan alat kelamin perempuan, merupakan suatu bentuk kekerasan dan streotipe gender terhadap kelompok tertentu dalam hal ini perempuan. ${ }^{24}$ Perbedaan dan peran gender sebenarnya bukan suatu masalah sepanjang tidak menimbulkan ketidakadilan dan ketidaksetaraan gender. Perlu ditekankan bahwa meskipun laki-laki dan perempuan dari sisi biologis berbeda, namun dari sisi sosial, lakilaki dan perempuan idealnya mempunyai peran dan tanggung jawab yang sama. Akan tetapi kondisi ideal tersebut belum tercipta karena masih terjadi ketidakadilan dan ketidaksetaraan atau diskriminasi gender.

Praktik sunat perempuan yang sudah merupakan tradisi dengan berbagai macam cara yang cenderung merugikan kesehatan reproduksi perempuan, perlu dirumuskan suatu kebijakan yang responsif dan berkeadilan gender serta nondiskriminatif. Sesuai dengan sistem hukum yang berlaku bahwa setiap peraturan perundang-undangan harus berlandasan pada asas hukum. Dalam sunat perempuan, asas hukum yang seharusnya dijadikan landasan adalah asas gender dan nondiskriminatif yang merupakan asas hukum responsif gender dengan tidak membedakan perlakuan yang diskriminatif terhadap perempuan. Asas Gender merupakan asas yang menciptakan suatu ideologi keadilan, kesetaraan dan nondiskriminasi, dimana asas gender bertujuan untuk melindungi perempuan dari ketidakadilan gender dan diskriminatif. Asas nondiskriminatif merupakan asas yang memiliki ideologi berkeadilan gender, tidak adanya perbedaan perlakukan, pembatasan atau pengucilan dan diskriminasi langsung maupun tidak langsung yang mengakibatkan pengurangan, penghapusan, pengakuan, penikmatan dan penggunaan hak.

Dalam Permenkes Sunat Perempuan, didalamnya memuat aturan pelaksanaan sunat perempuan terhadap organ reproduksi perempuan yang dilakukan oleh tenaga medis tertentu (dokter, bidan, perawat) merupakan suatu bentuk kekerasan dan diskriminasi terhadap perempuan. Dalam hal ini Permenkes Sunat Perempuan mengatur hak reproduksi perempuan yang seharusnya merupakan hak perempuan atas tubuh dan organ reproduksinya dan dijamin

22 Dayal Radha, 2007, CEDAW: Mengembalikan Hak Perempuan, Jakarta: SMK Grafika Desa Putera, HIm.13-14.

23 Ibid, HIm. 24-26.

24 Mansour Fakih, 2010, Analisis Gender dan Transformasi Sosial, Yogjakarta: Pustaka Pelajar,Cet. 13, HIm. 6. 
oleh undang-undang. Permenkes tentang sunat perempuan didalamnya berisi tentang tindakan sunat terhadap perempuan melanggar ketentuan hukum yang berperan untuk melindungi hak dan kesehatan reproduksi perempuan dengan berlandaskan kepada asas gender dan nondoskriminatif. Ketentuan sunat perempuan seharusnya memegang prinsip tentang hak reproduksi dan perlindungan terhadap perempuan dengan menggunakan landasan gender dan nondiskriminatif.

\section{PENUTUP}

\section{Simpulan}

Berdasarkan hasil penelitian dan pembahasan, dapat ditarik kesimpulan Ketentuan tentang Sunat Perempuan dikaitkan dengan Asas Gender dan Nondiskriminatif sebagai berikut:

a. Sunat perempuan masih dilakukan di beberapa wilayah dan kelompok masyarakat di Indonesia dengan berbagai variasi mulai secara simbolis, pengerokan sampai pemotongan ujung klitoris, berdasarkan adat, budaya dan agama. Sunat perempuan memiliki dampak buruk terhadap kesehatan reproduksi perempua. Konvensi CEDAW secara tegas melarang tindakan sunat perempuan. Undang-Undang No. 36 tahun 2009 tentang Kesehatan menjamin hak reproduksi perempuan dari bentuk kekerasan dan diskriminasi. Dalam meratifikasi CEDAW, Departemen Kesehatan tahun 2006 mengeluarkan Surat Edaran (SE) Dirjen Bina Kesehatan Masyarakat No. HK.00.07.1.3.10.47 tentang Larangan Medikalisasi Sunat Perempuan bagi Petugas Kesehatan. Dalam perjalanannya, Surat Edaran ini menimbulkan pro dan kontra. Salah satunya Majelis Ulama Indonesia (MUI) menyatakan bahwa Surat Edaran Dirjen Bina Kesehatan Masyarakat tentang Larangan Medikalisasi Sunat Perempuan bagi Petugas Kesehatan bertentangan dengan syariah Islam. Hal ini dinyatakan dengan mengeluarkan Fatwa MUI No.9A Tahun 2008 tentang Hukum Pelarangan Khitan terhadap Perempuan. Kementrian Kesehatan melakukan diskusi dengan berbagai pemangku kepentingan dalam rangka merespons Fatwa MUI dengan mengeluarkan Peraturan Menteri Kesehatan No. 1636/MENKES/PER/XI/2010 tentang Sunat Perempuan. Dalam Permenkes ini diatur pelaksanaan sunat perempuan sesuai dengan ketentuan agama, standar pelayanan, dan standar profesi untuk menjamin keamanan dan keselamatan perempuan yang disunat. Keluarnya Permenkes ini bertentangan dengan prinsip CEDAW dan melanggar hukum positif di Indonesia, terutama UUD 1945, UU HAM, UU Perlindungan Anak dan UU Kesehatan. Permenkes Sunat Perempuan yang dibuat dengan batasan khusus, tidak sesuai dengan ketentuan tentang standar pelayanan kesehatan dan standar profesi tenaga kesehatan.

b. Dalam sistem hukum di Indonesia asas hukum merupakan aturan dasar dan prinsip-prinsip hukum yang abstrak dan melatarbelakangi peraturan kongkrit dan pelaksanaan hukum. Undang-Undang No. 36 tahun 2009 tentang Kesehatan Pasal 2 menyatakan bahwa pembangunan kesehatan diselenggarakan dengan berasaskan perikemanusiaan, keseimbangan, manfaat, pelindungan, penghormatan terhadap hak dan kewajiban, keadilan, gender dan nondiskriminatif dan norma-norma agama. Dalam ketentuan tentang sunat perempuan berlaku asas gender dan nondiskriminatif. Asas Gender merupakan asas yang menciptakan suatu ideologi keadilan, kesetaraan dan nondiskriminasi, dimana asas gender bertujuan untuk melindungi perempuan dari ketidakadilan gender dan diskriminatif. Asas nondiskriminatif merupakan asas yang memiliki ideologi berkeadilan gender, tidak adanya perbedaan perlakukan, pembatasan atau pengucilan dan diskriminasi langsung maupun tidak langsung yang mengakibatkan pengurangan, penghapusan, pengakuan, penikmatan dan penggunaan hak. Dalam ketentuan tentang sunat perempuan, Permenkes Sunat perempuan tidak melindungi perempuan dari ketidakadilan gender dan kesetaraan gender dan bersifat diskriminasi terhadap perempuan dengan adanya streotipe dan subordinasi terhadap perempuan. 
c. Permenkes Sunat Perempuan yang berisi tentang tindakan sunat terhadap perempuan, melanggar ketentuan hukum yang berperan untuk melindungi hak dan kesehatan reproduksi perempuan. Ketentuan sunat perempuan harus mengacu pada prinsip tentang hak reproduksi dan perlindungan terhadap perempuan dengan menggunakan asas gender dan nondiskriminatif. Permenkes Sunat Perempuan tidak memenuhi asas gender dan nondisriminatif.

\section{Saran}

Berdasarkan kesimpulan di atas, maka dirumuskan saran dan rekomendasi sebagai berikut:

1. Pemerintah harus mencabut Permenkes No. 1636 tahun 2010 tentang Sunat Perempuan, karena bertentangan dengan Hukum Nasional dan Hukum Internasional tentang hak reproduksi perempuan (asas lex superior derogat legi inferiori), serta tidak sesuai dengan ketentuan standar pelayanan kesehatan dan standar profesi tenaga kesehatan.

2. Pemerintah seharusnya membuat peraturan tentang Sunat Perempuan dengan berasaskan gender dan nondiskriminatif yang bertujuan untuk melindungi hak dan kesehatan reproduksi perempuan.

3. Pemerintah melakukan sosialisasi pengarusutamaan gender yang dimulai dari pendidikan dasar sampai dengan pendidikan tinggi dengan mengintegrasikan kurikulum responsif gender, untuk meningkatkan kesadaran gender terutama anak perempuan dan perempuan tentang hak asasi, hak reproduksi perempuan dan praktik-praktik tradisional yang membahayakan kesehatan reproduksi.

4. Pemerintah melakukan sosialisasi tentang dampak sunat perempuan yang merugikan kesehatan reproduksi perempuan dengan melibatkan tenaga kesehatan dan lembaga swadaya perempuan yang bergerak dalam pemberdayaan perempuan.

\section{DAFTAR PUSTAKA}

\section{Buku Referensi:}

Agnes Widanti, 2005, Hukum Berkeadilan Jender, Jakarta: Buku Kompas.

Dayal, Radha, 2007, CEDAW: Mengembalikan Hak Perempuan, Jakarta: SMK Grafika Desa Putera.

F. Budi Hardiman, 2011, Hak-Hak Asasi Manusia: Polemik dengan Agama dan Kebudayaan, Yogyakarta: Kanisius.

Ida Soselo Wulan, 2012, Parameter Kesetaraan Gender Dalam Pembentukan Peratutan PerundangUndangan, Jakarta: Kementrian Pemberdayaan Perempuan dan Perlindungan Anak, Cetakan ke-2.

Johnny Ibrahim, 2010, Teori dan Metodelogi Penelitian Hukum Normatif, Bayumedia Publishing.

Kertas Kebijakan Kesetaraan Gender Indonesia, 2012, Jakarta: Kementrian Pemberdayaan Perempuan nan Perlindungan Anak RI dan Kementrian Perencanaan Pembangunan Nasional.

L.M.Gandhi Lapian, 2012, Disiplin Hukum yang Mewujudkan Kesetaraan dan Keadilan Gender, Jakarta: Yayasan Pustaka Obor Indonesia.

Mansour Fakih, 2010, Analisis Gender dan Transformasi Sosial, Yogyakarta: Pustaka Pelajar, Yogyakarta, Cet. 13.

Marwan Mas, 2011, Pengantar Ilmu Hukum, Bogor: Ghalia Indonesia. 
Rahmah Ida, 2005, Sunat Membelenggu Adat Perempuan Madura, Yogyakarta: Pusat Studi Kependudukan dan Kebijakan Universitas Gadjah Mada, Cet.Pertama.

Sumarni, 2005, Sunat Perempuan di bawah Bayang-Bayang Tradisi, Yogyakarta: Pusat studi Kependudukan dan Kebijakan Universitas Gadjah Mada.

Untung Suseno Sutarjo, 2010, Panduan Perencanaan dan Penganggaran Responsif Gender Bidang Kesehatan, Jakarta: Kementrian Kesehatan RI, Kementrian Pemberdayaan Perempuan dan Perlindungan Anak, UNFPA.

\section{Internet}

Anwar Ibrahim, 25 Juli 2012, Sunat Perempuan Dikecam LSM, Internet: http://at.tarmudzi.blogspot.com/2012/03

\section{Perundang-Undangan:}

Undang Undang Dasar Negara Republik Indonesia Tahun 1945.

Undang-Undang No. 36 tahun 2009 tentang Kesehatan.

Undang-Undang No. 29 Tahun 2004 tentang Praktik Kedokteran.

Undang-Undang No. 23 tahun 2002 tentang Perlindungan Anak.

Undang-Undang Nomor 39 Tahun 1999 tentang Hak Asasi Manusia.

Undang-Undang No. 7 Tahun 1984 tentang Pengesahan Konvensi Mengenai

Penghapusan Segala Bentuk Diskiriminasi Terhadap Wanita.

Peraturan Pemerintah No. 32 tahun 1996 tentang Tenaga Kesehatan.

Peraturan Presiden Nomor 5 Tahun 2010 tentang RPJMN Tahun 2010-2014.

Peraturan Presiden Nomor 7 Tahun 2005 tentang Rencana Pembangunan Jangka Menengah Nasional Tahun 2004- 2009.

Peraturan Menteri Kesehatan No. 1636 tahun 2010 tentang Sunat Perempuan.

Permenkes No. 1464 tahun 2010 tentang Izin dan Penyelenggaraan Praktik Bidan.

Permenkes No. 148 tahun 2010 tentang Izin dan Penyelenggaraan Praktik Perawat.

Kepmenkes No. 369 tahun 2007 tentang Standar Profesi Bidan.

Surat Edaran (SE) Dirjen Bina Kesehatan Masyarakat No. HK.00.07.1.3.10.47

tentang Larangan Medikalisasi Sunat Perempuan bagi Petugas Kesehatan.

Fatwa MUI No.9A Tahun 2008 tentang Hukum Pelarangan Khitan terhadap Perempuan. 